
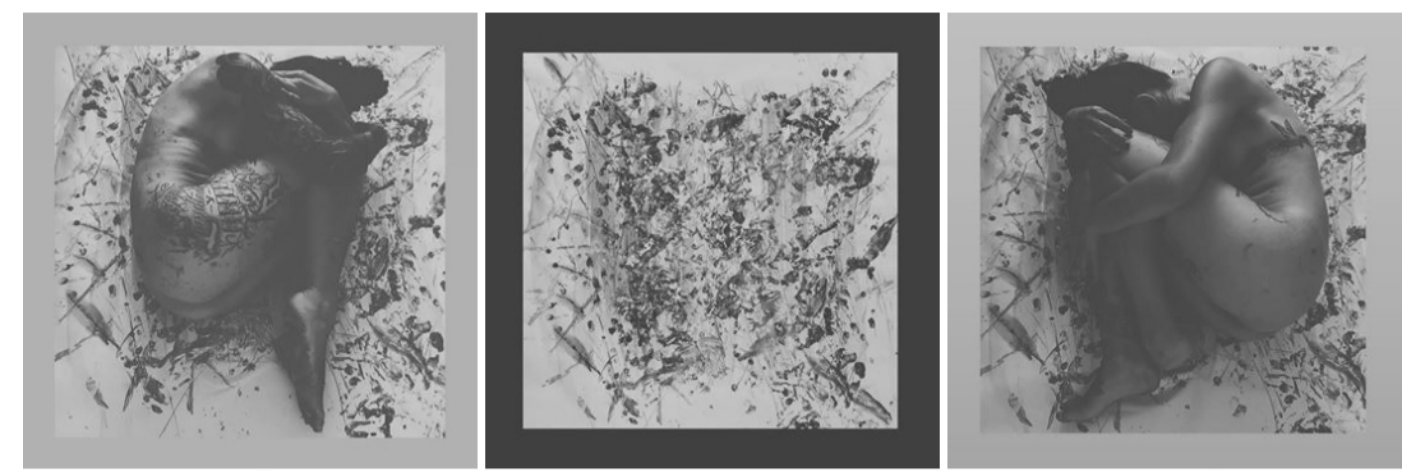

\title{
Autoretrato sobre una exploración
}

Trece de Septiembre de 2020.

\section{Reflexión}

Creadora visual, especialmente interesada en los procesos creativos y el poder terapéutico del arte. Mis trabajos más recientes se basan en la fijación en los detalles, en una búsqueda que siento necesaria, de encuentro con la sencillez y el silencio, de representar una realidad de la que me interesa el reflejo de los procesos vitales, luces y sombras, en contextos y elementos naturales a través de la auto - observación y herramientas como la escritura, la fotografía, el collage y el dibujo principalmente.

\section{Autora}

Virginia Martínez

Licenciada en Bellas Artes (Universidad de Granada).

II Curso de Terapias Creativas y Mediación Artística como métodos de intervención en contextos educativos, sociales y asistenciales (Universidad de Murcia).

Arteterapia: papeles de arteterapia y educación artística para la integración social.

Monográfico: Las miradas del arte y el arteterapia en tiempos de la Covid19. ISSN-e: 1988-8309 https://dx.doi.org/10.5209/arte.75918 